\title{
Secondary Combined Immunodeficiency in Pediatric Patients after the Fontan Operation: Three Case Reports
}

\author{
Eva Hlavackova ${ }^{a, b}$ Martin Liska ${ }^{d, e}$ Hana Jicinska ${ }^{c}$ Jiri Navratil ${ }^{c}$ \\ Jiri Litzman ${ }^{a, b}$ \\ aDepartment of Clinical Immunology and Allergology, St. Anne's University Hospital, and b Faculty of Medicine, \\ Masaryk University, and ' Department of Pediatric Cardiology, Pediatric Department, Brno University Hospital, \\ Brno, d Department of Immunology and Allergology, Faculty of Medicine, and eFaculty Hospital in Pilsen, Charles \\ University, Prague, Czech Republic
}

\section{Established Facts}

- The Fontan procedure represents a palliative surgical correction of rare congenital heart defects. Protein-losing enteropathy (PLE) develops in $4-13 \%$ of patients after the Fontan operation, rapidly decreasing the life expectancy of these patients.

- Secondary combined immunodeficiency in patients with Fontan-related PLE is predominantly characterized by severe hypogammaglobulinemia and profound $\mathrm{CD}^{+}$lymphocytopenia.

\section{Novel Insights}

- Subcutaneous immunoglobulin replacement therapy in patients with Fontan-related PLE does not markedly elevate the total IgG levels but reduces the number of infections.

- Heart transplantation led to complete immunoglobulin level recovery and PLE sign resolution in an individual case.

\section{Key Words}

Fontan operation · Protein-losing enteropathy · Secondary combined immunodeficiency · Hypogammaglobulinemia . $\mathrm{CD}^{+}$lymphocytopenia

\section{Abstract \\ The Fontan operation or total cavopulmonal connection (TCPC) is a palliative surgical correction of rare and complex inborn cardiac malformations that are characterized by uni-}

ventricular circulation. Protein-losing enteropathy (PLE) develops in 4-13\% of patients after the Fontan procedure. Fontan-related PLE leads to secondary combined immunodeficiency marked by hypogammaglobulinemia and predominantly CD4+ Iymphocytopenia. Here, we present 3 case reports of patients with secondary immunodeficiency after the Fontan operation. The severity of hypogammaglobulinemia correlated with the nature of the infectious complications; however, clinical manifestations of T cell deficiency such as severe viral or opportunistic infections were not observed.

\section{KARGER}

E-Mail karger@karger.com www.karger.com/iaa
C 2016 S. Karger AG, Basel

$1018-2438 / 16 / 1704-0251 \$ 39.50 / 0$
Correspondence to: Prof. Jiri Litzman

Department of Clinical Immunology and Allergology

St. Anne's University Hospital, Masaryk University

Pekarska 53, CZ-656 91 Brno (Czech Republic)

E-Mail jiri.litzman@fnusa.cz 
The clinical consequences of the secondary combined immunodeficiency were modified by immunoglobulin replacement treatment and antibiotic prophylaxis. Heart transplantation led to the resolution of PLE signs and the restitution of IgG levels in 1 transplanted patient. Our experience shows that the immunological follow-up was delayed in all 3 patients. We suggest that all patients should be followed regularly by a clinical immunologist after the Fontan surgery.

(c) 2016 S. Karger AG, Basel

\section{Introduction}

Several rare and complex inborn heart anomalies that are marked by an underdeveloped left side of the heart or a defect of the heart valves can be corrected by a series of palliative surgeries that are finalized by the Fontan procedure (total cavopulmonal connection, TCPC) [1]. The main inborn heart defect that is corrected by TCPC is hypoplastic left heart syndrome (HLHS), with an incidence of $0.16-0.36$ per 1,000 live births [2-4]. Less frequent are double-inlet left ventricle, tricuspid atresia and pulmonary atresia with intact ventricular septum $[5,6]$. Seventy percent of patients with HLHS are expected to reach adulthood; however, the long-term prognosis of these patients remains unpredictable [7].

In 'Fontan circulation', the systemic venous return is connected to the pulmonary arteries without the interposition of an adequate ventricle, and all shunts are interrupted on the venous, atrial, ventricular and arterial levels [3]. After Fontan operation, patients live in a unique state of central venous hypertension, with a relatively diminished cardiac output [8].

Regional circulatory abnormalities caused by an abnormal elevation of the mesenteric vascular resistance are suggested to contribute to the development of Fontan-related protein-losing enteropathy (PLE) [8]. PLE occurs in $4-13 \%$ of patients after the Fontan operation with the median onset being 10 years after the procedure [9]. The 5-year survival rate after Fontan-related PLE manifestation varies between 46 and 59\% [10, 11]. Together with plastic bronchitis, PLE is a late, life-threatening complication in these patients [8]. PLE is characterized by excessive protein loss through the gastrointestinal mucosa [1].This conditionleads to hypoalbuminemia, hypoproteinemia, elevated alpha-1-antitrypsin clearance, lymphocytopenia and hypocalcemia that are marked clinically by ascites, edema of the limbs, pleural and cardiac effusions and muscle cramps [10-12].
Immunological investigations in patients with Fontan-related PLE have revealed secondary abnormalities in humoral and cellular immunity [13-16]. The most prominent features are secondary hypogammaglobulinemia together with lymphocytopenia, affecting predominantly $\mathrm{CD} 4^{+}$cells $[8,9,14,15,17]$.

The reason why PLE develops in these patients is not yet clear [11]. Diminished mesenteric flow caused by increased mesenteric vascular resistance could be the main cause of PLE in patients with univentricular circulation $[8,18]$. It is speculated that chronically elevated central venous pressure together with a low cardiac output leads to the rearrangement of the lymphatic system and protein leakage, causing PLE in the gut and plastic bronchitis in the respiratory tract $[8,19]$. Here, we present 3 patients with complex congenital heart anomalies that were corrected by the Fontan procedure and complicated by PLE with secondary combined immunodeficiency.

\section{Case Report 1}

A boy with HLHS underwent the Fontan procedure at the age of 5 years after a series of previous reconstructive palliative heart surgeries. From infancy, his weight and growth measurements were near the 3 rd percentile. Intermittent edema of the eyelids and ascites manifested 4 months after TCPC, when the first episode of pneumonia was also documented. Every year after TCPC, he experienced approximately 6 respiratory tract infections of suspicious bacterial origin that required antibiotic treatment. At the age of 9 years, the patient suffered from pneumonia complicated by fluidothorax. From the age of 12 years, recurrent lower limb effusions, abdominal pain and hepatomegaly with undulating ascites were present. Severe osteoporosis caused by chronic hypocalcemia led to compressive thoracic vertebra fracture. Another episode of pneumonia accompanied by ascites and hepatomegaly occurred at the age of 15 years. Despite recurrent respiratory tract infections, no complication could have been considered to be an opportunistic infection.

The laboratory findings at the age of 5 years revealed incipient PLE with hypogammaglobulinemia and hypoproteinemia (table 1). The first extensive immunological examination was performed at the age of 9 years, revealing predominately IgG hypogammaglobulinemia with $\mathrm{CD} 4^{+}$lymphocytopenia. IgA and IgM levels decreased during the follow-up period (tables 1, 2). IgG1 ( $1.56 \mathrm{~g} / \mathrm{l}$; ref. range $3.70-12.80 \mathrm{~g} / \mathrm{l})$, IgG2 (0.45g/l; ref. range $1.06-$ $6.10 \mathrm{~g} / \mathrm{l})$ and IgG3 (0.11 g/l; ref. range $0.18-1.63 \mathrm{~g} / \mathrm{l})$ levels were reduced, while IgG4 levels stayed within the reference range. Previously decreased anti-Haemophilus influenzae type b (Hib)-specific antibodies $(0.01 \mathrm{mg} / \mathrm{l}$; ref. range $0.09-17.70 \mathrm{mg} / \mathrm{l})$ normalized $(0.43 \mathrm{mg} / \mathrm{l})$ after revaccination at the age of 9 years. Antibodies against a mixture of pneumococcal capsular polysaccharide antigens (PCP) of 23 serotypes included in the nonconjugated antipneumococcal vaccines temporarily increased (3.60 mg/l) after revaccination with an anti-pneumococcal vaccine (Pneumo 23, Sanofi Pasteur SA, France) without reaching the reference range $(>15.40 \mathrm{mg} / \mathrm{l})$. Anti-tetanus-specific antibodies stayed within the
Hlavackova/Liska/Jicinska/Navratil/ Litzman 
Table 1. Immunoglobulin, total protein and albumin levels in patients $1-3$ at different follow-up time points

\begin{tabular}{|c|c|c|c|c|c|c|c|c|c|c|}
\hline & \multicolumn{4}{|c|}{ Patient 1} & \multicolumn{3}{|c|}{ Patient 2} & \multicolumn{3}{|l|}{ Patient 3} \\
\hline & 5 years & 11 years & 15 years & 17 years $^{\mathrm{a}}$ & 8 years & 15 years & 17 years & 6 years $^{b}$ & 11 years & 12 years \\
\hline IgG, g/l (7.50-15.60) & 1.00 & 2.06 & 1.24 & 12.00 & n.a. & 1.11 & 2.76 & 13.43 & 2.31 & 1.94 \\
\hline $\operatorname{IgA}, \mathrm{g} / \mathrm{l}(0.70-2.30)$ & 0.70 & 0.64 & 0.54 & 1.00 & n.a. & 0.25 & 0.38 & 0.66 & 0.26 & 0.18 \\
\hline $\mathrm{IgM}, \mathrm{g} / \mathrm{l}(0.40-1.50)$ & 0.56 & 0.42 & n.a. & 0.71 & n.a. & 0.92 & 0.96 & 1.32 & 0.24 & 0.17 \\
\hline Total protein, g/l $(35-52)$ & 23.30 & 28.20 & 15.60 & 43.00 & 44.00 & 41.40 & 43.50 & 71.30 & n.a. & 47.60 \\
\hline Albumin, g/l $(64-83)$ & 41.20 & 47.80 & 37.80 & 71.70 & 24.00 & 22.00 & 19.70 & 48.60 & n.a. & 33.20 \\
\hline
\end{tabular}

The reference range for the healthy population is given in parentheses. n.a. = Not analyzed.

a After heart transplantation. ${ }^{\mathrm{b}}$ Before Fontan operation.

Table 2. Lymphocyte subset, leukocyte and lymphocyte counts in patients $1-3$ at different follow-up time points

\begin{tabular}{|c|c|c|c|c|c|c|c|}
\hline \multirow[t]{2}{*}{ Count } & \multicolumn{4}{|c|}{ Patient 1} & \multirow{2}{*}{$\frac{\text { Patient } 2}{16 \text { years }}$} & \multicolumn{2}{|l|}{ Patient 3} \\
\hline & 9 years & 13 years & 15 years & 17 years $^{\mathrm{a}}$ & & 10 years & 11 years \\
\hline Leukocytes, $\times 10^{9} / 1(3.60-10.00)$ & 8.40 & 9.20 & 9.00 & 9.30 & 10.00 & 8.80 & 36.67 \\
\hline Lymphocytes, \% (25-40) & 1.00 & 1.00 & 2.00 & 8.00 & 1.00 & 14.40 & 21.00 \\
\hline $\mathrm{CD}^{+}, \%(58-85)$ & 29.00 & 25.00 & 35.00 & 66.00 & 37.00 & 38.90 & 1.04 \\
\hline $\mathrm{CD}^{+}, \times 10^{9} / 1(0.90-2.80)$ & 0.05 & 0.06 & 0.03 & 0.49 & 0.18 & 0.49 & 0.06 \\
\hline $\mathrm{CD}^{+}, \%(30-60)$ & 8.00 & 7.00 & 13.00 & 15.00 & 12.00 & 6.68 & 22.80 \\
\hline $\mathrm{CD}^{+}, \times 10^{9} / 1(0.40-1.40)$ & 0.01 & 0.02 & 0.01 & 0.11 & 0.06 & 0.08 & 0.13 \\
\hline $\mathrm{CD}^{+}, \%(15-35)$ & 18.00 & 16.00 & 23.00 & 51.00 & 24.00 & 26.77 & 30.45 \\
\hline $\mathrm{CD}^{+}, \times 10^{9} / 1(0.20-0.90)$ & 0.03 & 0.04 & 0.02 & 0.38 & 0.12 & 0.34 & 0.17 \\
\hline $\mathrm{CD} 19^{+}, \%(7.0-23)$ & 27.00 & 6.00 & 12.00 & 10.00 & 9.0 & 15.89 & 28.10 \\
\hline $\mathrm{CD}_{19}+, \times 10^{9} / 1(0.20-0.60)$ & n.a. & n.a. & 0.01 & 0.07 & n.a. & 0.20 & 0.16 \\
\hline $\mathrm{CD} 16^{+} / \mathrm{CD}^{2} 6^{+}, \%(6-20)$ & 42.00 & 69.00 & 50.00 & 23.00 & 54.00 & 41.84 & 5.80 \\
\hline $\mathrm{CD} 16^{+} / \mathrm{CD} 56^{+}, \times 10^{9} / 1(0.07-0.20)$ & n.a. & n.a. & 0.05 & 0.17 & n.a. & 0.53 & 9.60 \\
\hline
\end{tabular}

The reference range for the healthy population is given in parentheses. n.a. $=$ Not analyzed.

a After heart transplantation.

reference range during the follow-up period $(4.77 \mathrm{IU} / \mathrm{ml}$; ref. range $>0.12 \mathrm{IU} / \mathrm{ml}$ ). Complement components $\mathrm{C} 3$ and $\mathrm{C} 4$ did not reveal any abnormalities.

Profound decreases in the absolute and relative numbers of $\mathrm{CD}^{+}{ }^{+} \mathrm{CD} 4^{+}$cells and decreases in the absolute numbers of $\mathrm{CD}^{+} \mathrm{CD}^{+}, \mathrm{CD} 19^{+}$and $\mathrm{CD} 16^{+} / 56^{+}$lymphocytes were observed during the follow-up period (table 2 ). No abnormality in the number of $\mathrm{CD}^{+} \gamma / \delta \mathrm{T}$ cells was observed. A marked reduction of naïve CD45RA ${ }^{+}$cells (3.80\%; ref. range $\left.40.90-65.70 \%\right)$ and a predominance of memory CD $45 \mathrm{RO}^{+}$cells $(95.80 \%$; ref range $25.10-52.10 \%)$ were observed among $\mathrm{CD} 4^{+} \mathrm{T}$ cells. The CD45RA ${ }^{+}$cells $(54.5 \%$; ref. range 61.00-91.00\%) decreased continuously during the follow-up period, accompanied by a continuous increase in the proportion of $\mathrm{CD} 45 \mathrm{RO}^{+}$cells $(49.20 \%$; ref. range $13.00-29.30 \%$ ) among $\mathrm{CD}^{+}$cells. The expression levels of other activation markers stayed within their reference ranges $\left(\mathrm{CD} 4^{+} \mathrm{HLADR}^{+}: 4.30 \%\right.$; ref. range $4-11 \%$ and $\mathrm{CD}^{+} \mathrm{HLADR}^{+}$: $18 \%$; ref. range $\left.5-25 \%\right)$. An evaluation of $\mathrm{B}$ cell subsets revealed significantly increased transi- tional B cells $\left(\mathrm{CD} 24^{++} \mathrm{CD} 38^{++}\right)$. Naive B cells $\left(\mathrm{IgM}^{+} \mathrm{CD} 27^{-}\right)$, marginal zone B cells $\left(\mathrm{IgM}^{+} \mathrm{CD} 27^{+}\right)$and memory B cells $\left(\mathrm{IgM}^{-} \mathrm{CD} 27^{+}\right)$ stayed within the normal ranges. Plasmablasts $\left(\mathrm{CD} 27^{+++} \mathrm{CD} 38^{+++}\right.$) and $\mathrm{CD} 21^{\text {low }} \mathrm{CD} 38^{\text {low }} \mathrm{B}$ cells were slightly reduced (table 3 ).

Sulfamethoxazole trimethoprim prophylaxis (a dose of $5 \mathrm{mg}$ / $\mathrm{kg} /$ day once daily 3 days a week) was introduced at the age of 10 years; however, the effect of this treatment on the frequency and severity of respiratory tract infections was only marginal. At the age of 15 years, subcutaneous immunoglobulin substitution therapy $(0.08 \mathrm{~g} / \mathrm{kg} /$ per week $)$ was initiated. Despite the occurrence of only a minor increase in serum IgG levels from 1.55 to $2.45 \mathrm{~g} / \mathrm{l}$, a decrease in the number of respiratory infections was observed.

The patient's hemodynamic state deteriorated rapidly, demanding the implantation of a ventricular assistant device at the age of 16 years. Heart transplantation was carried out 6 months later. One year after the transplantation, the patient was hemodynamically stable without any infectious complications or clinical symptoms or signs of PLE. 
Table 3. B lymphocyte subsets in patient 1

\begin{tabular}{lrrr}
\hline & 15 years & 17 years & 17 years $^{\text {a }}$ \\
\hline IgM $^{+} \mathrm{CD} 27^{-}, \%(75.20-86.70)$ & 68.80 & 85.30 & 85.30 \\
IgM $^{+} \mathrm{CD} 27^{+}, \%(4.60-10.20)$ & 5.50 & 4.60 & 1.00 \\
IgM $^{-} \mathrm{CD} 27^{+}, \%(3.30-9.60)$ & 5.40 & 6.80 & 0.70 \\
$\mathrm{CD} 24^{++} \mathrm{CD} 38^{++}, \%(2.30-5.50)$ & 41.00 & 56.80 & 25.40 \\
$\mathrm{CD} 27^{++} \mathrm{CD} 38^{+++}, \%(0.30-1.70)$ & 5.00 & 3.60 & 0.10 \\
$\mathrm{CD} 21^{\text {low } C D 38^{\text {low }}, \%(0.90-3.30)}$ & 5.90 & 5.80 & 1.50 \\
\hline
\end{tabular}

The reference range for the healthy population is given in parentheses. B lymphocyte subset nomenclature: $\operatorname{IgM}^{+} \mathrm{CD} 27^{-}=$naïve cells, $\operatorname{IgM}^{+} \mathrm{CD} 27^{+}=$marginal zone cells, $\operatorname{IgM}^{-} \mathrm{CD} 27^{+}=$memory cells, CD $24^{++} \mathrm{CD} 38^{++}=$transitional cells, $\mathrm{CD} 27^{+++} \mathrm{CD} 38^{+++}=$plas mablasts, $\mathrm{CD} 21^{\text {low }} \mathrm{CD} 38^{\text {low }}$ cells.

${ }^{a}$ After heart transplantation.

The heart transplantation led to the normalization of the absolute numbers of $\mathrm{CD}^{+} \mathrm{CD}^{+}, \mathrm{CD} 16^{+} / 56^{+}$and $\mathrm{CD} 19^{+}$cells. The absolute and relative numbers of $\mathrm{CD} 3^{+} \mathrm{CD} 4^{+}$cells were partially elevated but remained reduced (table 2). Serum IgG and also IgM levels normalized within 4 months after the transplantation (table 1), leading to the discontinuation of immunoglobulin treatment. The levels of anti-PCP antibodies $(28.30 \mathrm{mg} / \mathrm{l})$ reached the reference range without the necessity of revaccination after transplantation. In addition, hypoalbuminemia and hypoproteinemia diminished after the transplantation.

\section{Case Report 2}

The second patient, a boy with double-outlet left ventricle, underwent a series of palliative heart surgeries in infancy, followed by TCPC at the age of 3 years. The first signs of PLE were observed at the age of 6 years, verified by increased alpha-1-antitrypsin clearance. At the age of 8 years, the patient manifested with transitional diarrhea and edema of the abdomen and the eyelids. At the age of 12 years, severe diarrhea occurred, accompanied by edema of the face and ascites with hepatomegaly. Progressive hypoalbuminemia, hypoproteinemia (table 1$)$, hypocalcemia ( $1.64 \mathrm{mmol} / \mathrm{l}$; ref. range $2.15-2.51 \mathrm{mmol} / \mathrm{l})$ and hypomagnesemia $(0.68 \mathrm{mmol} / \mathrm{l}$; ref. range $0.71-0.94 \mathrm{mmol} / \mathrm{l}$ ) with cramps and growth retardation were present. Low-molecular-weight heparin, diuretics, corticosteroids and a low-protein diet yielded only mild effects. Frequent upper and lower respiratory tract infections, including 1 episode of pneumonia, with at least 3 antibiotic courses each year, lowered the patient's quality of life. The patient's hemodynamic state deteriorated rapidly. Edema of the lower extremities, ascites, hypocalcemic cramps and diarrhea manifested even during calcium and iron substitution, nutritional supplementation and forced complex anti-edematous therapy. Prophylaxis with amoxicillin-clavulanic acid was introduced at the age of 15 years; however, the effect on the frequency of respiratory tract infections was only marginal. No infection could have been considered to be opportunistic. Heart transplantation was considered, but the patient died of malignant arrhythmia after contracting severe Campylobacter jejuni gastroenteritis at the age of 16 years.

The first immunological investigation at the age of 15 years had revealed profound IgG hypogammaglobulinemia and slight IgA hypogammaglobulinemia with normal IgM levels (table 1 ). Severe $\mathrm{CD}^{+} \mathrm{CD}^{+}$lymphocytopenia, accompanied by a decrease in the $\mathrm{CD}^{+}{ }^{+} \mathrm{CD}^{+}{ }^{+}$subset, was present (table 2$)$. Anti-PCP $(0.68 \mathrm{mmol} / \mathrm{l})$ and anti-tetanus toxoid (3.90 IU/ml) specific antibody levels were deeply depressed. Anti-Hib antibodies (0.61 mg/l) stayed within the reference range.

\section{Case Report 3}

A boy with HLHS underwent TCPC at the age of 8 years. The patient had a history of a series of palliative heart surgeries in infancy. At the age of 2 years, he suffered from recurrent respiratory tract infections and 1 episode of pneumonia. Afterwards, he remained stable until the age of 10 years, when recurrent, uncomplicated lower and upper respiratory tract infections occurred, including otitis media and bronchitis without any opportunistic infection cause.

Intermittent diarrhea without a documented infectious agent was present. No signs or symptoms of effusions, ascites or edema were present. Antibiotic prophylaxis with amoxicillin-clavulanic acid was introduced at the age of 10 years.

The first immunoglobulin examination at the age of 2 years revealed decreased IgG and IgM, which normalized in the following year. Severe IgG hypogammaglobulinemia, followed by decreased IgA and IgM, was observed at the age of 8 years (table 1$)$. The patient's IgG1 (1.65 g/l), IgG2 (0.18 g/l), and IgG3 (0.19 g/l) levels were reduced. Subcutaneous immunoglobulin substitution $(0.10$ $\mathrm{g} / \mathrm{kg} /$ week) was initiated at the age of 10 years, with a minimal laboratory serum IgG increase (from 1.65 to $3.44 \mathrm{~g} / \mathrm{l}$ ) but positive clinical effects. Albumin and total protein levels were profoundly reduced. Absolute $\mathrm{CD}^{+} \mathrm{CD}^{+}$lymphocytopenia was present; however, other lymphocyte subpopulations remained within the reference range (table 2). At the time of the completion of this study, the patient, who was 11 years old, had a good quality of life with the absence of respiratory tract infections.

\section{Discussion}

Here we present 3 case reports of patients with Fontanrelated PLE. We observed CD4 lymphocytopenia and IgG hypogammaglobulinemia, with a predominant IgG1 and IgG2 decrease in all 3 patients. Combined secondary immunodeficiency manifested as recurrent respiratory tract infections. No opportunistic infection was observed. Immunoglobulin replacement therapy accompanied by antibiotic prophylaxis led to a decrease in the number of respiratory infections. In 1 patient, heart transplantation resulted in the restitution of the hemodynamic state and laboratory findings.

The mechanism that leads to secondary immunodeficiency in patients with PLE after TCPC is not fully under- 
stood. The reduction of immunoglobulin levels can be explained by the loss of immunoglobulins into the gastrointestinal tract [16]. A predominant IgG decrease can be explained by the extensive loss of proteins [20] with slow turnover, including albumin and IgG [1]. In contrast, proteins with shorter half-lives, such as clotting factors, prealbumin or transferrin, are preserved nearly in the normal range $[1,4]$. It is speculated that lymphocytopenia in PLE develops due to abnormal intraluminal lymphatic drainage [17]. Radiolabeled lymphocytes were detected in the stools of patients suffering from PLE [21]. Predominant $\mathrm{CD} 4^{+}$lymphocytopenia can be explained by an elevated CD4/CD8 ratio in the lymph caused by the selective transport of $\mathrm{CD} 4^{+}$cells in the lymph or the shorter half-life of the $\mathrm{CD} 8^{+}$subset in comparison to the $\mathrm{CD} 4^{+}$ lymphocyte subset $[14,22]$.

In all of our patients, decreases in IgG, IgG1, IgG2 and IgA were observed, which is consistent with previous findings in Fontan-related PLE patients [9, 15, 17]. IgM, together with IgG3, was decreased only in patients 1 and 3 . This variability is consistent with other published data $[15,17]$. The severe predominately $\mathrm{CD} 4^{+}$lymphocytopenia in all patients corresponds with reports in the literature $[15,17]$. We observed decreased absolute counts of $\mathrm{CD} 19^{+} \mathrm{B}$ and $\mathrm{CD} 16 / 56^{+} \mathrm{NK}$ cells in patients 1 and 2 . In contrast, a normal absolute $\mathrm{B}$ cell count was observed by Magdo et al. [17].

The $\mathrm{CD} 4{ }^{+} \mathrm{CD} 45 \mathrm{RA}^{+}$subset was markedly decreased in all of our patients when measured. $\mathrm{CD}^{+} \mathrm{CD} 45 \mathrm{RA}^{+}$cells decreased continuously during the follow-up period. A markedly elevated transitional B cell subset dominated in patient 1 (table 3). To our knowledge, B cell subsets in Fontan-related PLE patients have not yet been described in the literature.

Specific antibodies revealed a decrease in anti-PCP antibodies in all 3 patients. In patient 1, anti-PCP antibodies showed only a transient increase after revaccination with the 23-valent polysaccharide vaccine. However, after cardiac transplantation, the serum anti-PCP antibodies normalized. Magdo et al. [17] also described a decrease in anti-PCP antibodies in Fontan-related PLE patients. Decreased anti-Hib antibodies normalized after revaccination in patient 1 and were normal in patient 2 . In contrast to the data available in the literature [17], we observed decreased anti-tetanus toxoid antibodies in patient 2 .

Heart transplantation in patient 1 led to full immunoglobulin level restitution. Despite the normalization of the $\mathrm{CD}^{+} \mathrm{CD}^{+}$and $\mathrm{CD} 16^{+} / 56^{+}$lymphocyte subsets, $\mathrm{CD}^{+} \mathrm{CD}^{+}$cells and the $\mathrm{CD} 4^{+} \mathrm{D} 45 \mathrm{RA}^{+}$subset showed only a slight increase, remaining deeply below the refer- ence range. $\mathrm{CD} 19^{+}$lymphocyte subsets were elevated in absolute counts without reaching the reference range (table 2). The $\mathrm{CD} 3^{+} \mathrm{CD} 4^{+}$count was influenced by immunosuppressive therapy in this patient.

Yamamoto et al. [14] described a patient with primary intestinal lymphangiectasia, in whom $\mathrm{CD} 4^{+}$counts also failed to normalize 6 months after successful treatment with a medium-chain triglyceride diet and IgG restitution.

The levels of immunoglobulins correlated with the clinical severity of secondary immunodeficiency in each patient. The nature and localization of the infection courses were characteristic of hypogammaglobulinemia but not $\mathrm{CD}^{+}$lymphocytopenia. Our patients suffered predominantly from respiratory tract infections that are typical of antibody deficiency. Despite severe $\mathrm{CD} 4^{+}$lymphocytopenia, no infectious complication associated with CD4 deficiency (Pneumocystis jirovecii pneumonia, mycobacterial infection, mycotic infections and severe infections caused by the viruses of the herpes virus family) manifested in our patients. This finding is consistent with the observation of Magdo et al. [17].

Antibiotic prophylaxis yielded only a mild clinical effect in our patients. Intravenous and subcutaneous immunoglobulin treatment has been proven to be effective in patients with primary hypogammaglobulinemia [23]. Zaupper et al. [24] reported the resolution of cardiac-related PLE symptoms after high-dose ( $1 \mathrm{~g} / \mathrm{kg} / 4$ weeks) intravenous immunoglobulin treatment. Despite the insufficient IgG increase in our patients, which was probably caused by the massive loss in the gut, subcutaneous immunoglobulin replacement therapy at a dose of 0.080 $0.100 \mathrm{~g} / \mathrm{kg} /$ week markedly decreased the number of infection courses in both of our patients when applied.

\section{Conclusion}

Fontan-related PLE is a life-expectancy-reducing condition that is marked by massive protein loss and subclinical combined secondary immunodeficiency. Hypogammaglobulinemia, predominantly $\mathrm{CD} 4^{+}$lymphocytopenia, and a variably reduced response to vaccination are the main laboratory features of this condition. Our patients suffered from recurrent respiratory tract infections but not opportunistic infections. Subcutaneous immunoglobulin substitution, together with antibiotic prophylaxis, increased their quality of life by decreasing the number of infection courses. We recommend that patients after TCPC with complex cardiac anomalies should be followed regularly by a clinical immunologist. 


\section{Acknowledgements}

This publication was written at Masaryk University as part of the project 'Patogeneza a léčba humorálních imunodefciencí,' with the support of the Specific University Research Grant MUNI/A/1183/2015, which was provided by the Ministry of Education, Youth and Sports of the Czech Republic in the year 2016.

\section{Statement of Ethics}

The publication of this article was approved by the ethic committee of St. Anne's University Hospital in Brno.

\section{References}

1 Braamskamp MJ, Dolman KM, Tabbers MM: Clinical practice. Protein-losing enteropathy in children. Eur J Pediatr 2010;169:11791185.

2 Connor JA, Thiagarajan R: Hypoplastic left heart syndrome. Orphanet J Rare Dis 2007;2: 23.

3 Gewillig M: The Fontan circulation. Heart 2005;91:839-846.

4 Takeda H, Ishihama K, Fukui T, et al: Significance of rapid turnover proteins in proteinlosing gastroenteropathy. Hepatogastroenterology 2003;50:1963-1965.

5 Shinebourne EA, Rigby ML, Carvalho JS: Pulmonary atresia with intact ventricular septum: from fetus to adult: congenital heart disease. Heart 2008;94:1350-1357.

6 Gewillig M, Brown SC, Eyskens B, et al: The Fontan circulation: who controls cardiac output? Interact Cardiovasc Thorac Surg 2010; 10:428-433.

7 Barron DJ, Kilby MD, Davies B, Wright JG, Jones TJ, Brawn WJ: Hypoplastic left heart syndrome. Lancet 2009;374:551-564.

8 Rychik J, Goldberg DJ: Late consequences of the Fontan operation. Circulation 2014;130: $1525-1528$.

9 Chakrabarti S, Keeton BR, Salmon AP, Vettukattil JJ: Acquired combined immunodeficiency associated with protein-losing enteropathy complicating Fontan operation. Heart 2003;89:1130-1131.

10 Silvilairat S, Cabalka AK, Cetta F, Grogan M, Hagler DJ, O'Leary PW: Protein-losing enteropathy after the Fontan operation: associations and predictors of clinical outcome. Congenit Heart Dis 2008;3:262-268.
11 Feldt RH, Driscoll DJ, Offord KP, et al: Protein-losing enteropathy after the Fontan operation. J Thorac Cardiovasc Surg 1996;112: 672-680.

12 Mertens L, Hagler DJ, Sauer U, Somerville J, Gewillig M: Protein-losing enteropathy after the Fontan operation: an international multicenter study. PLE study group. J Thorac Cardiovasc Surg 1998;115:1063-1073.

13 Weiden PL, Blaese RM, Strober W, Block JB, Waldmann TA: Impaired lymphocyte transformation in intestinal lymphangiectasia: evidence for at least two functionally distinct lymphocyte populations in man. J Clin Invest 1972;51:1319-1325.

14 Yamamoto H, Tsutsui T, Mayumi M, Kasakura S: Immunodeficiency associated with selective loss of helper/inducer T cells and hypogammaglobulinaemia in a child with intestinal lymphangiectasia. Clin Exp Immunol 1989;75:196-200.

15 Koch A, Hofbeck M, Feistel H, Buheitel G Singer H: Circumscribed intestinal protein loss with deficiency in CD4+ lymphocytes after the Fontan procedure. Eur J Pediatr 1999; 158:847-850.

16 Strober W, Wochner RD, Carbone PP, Waldmann TA: Intestinal lymphangiectasia: a protein-losing enteropathy with hypogammaglobulinemia, lymphocytopenia and impaired homograft rejection. J Clin Invest 1967;46:1643-1656.
17 Magdo HS, Stillwell TL, Greenhawt MJ, et al: Immune abnormalities in Fontan proteinlosing enteropathy: a case-control study. J Pediatr 2015;167:331-337.

18 Rychik J, Gui-Yang S: Relation of mesenteric vascular resistance after Fontan operation and protein-losing enteropathy. Am J Cardiol 2002;90:672-674.

19 Ohuchi H, Yasuda K, Miyazaki A, et al: Haemodynamic characteristics before and after the onset of protein-losing enteropathy in patients after the Fontan operation. Eur J Cardiothorac Surg 2013;43:49-57.

20 Onigbanjo MT, Orange JS, Perez EE, Sullivan KE: Hypogammaglobulinemia in a pediatric tertiary care setting. Clin Immunol 2007;125: 52-59.

21 Müller C, Wolf H, Göttlicher J, Zielinski CC Eibl MM: Cellular immunodeficiency in protein-losing enteropathy. Predominant reduction of CD3+ and CD4+ lymphocytes. Dig Dis Sci 1991;36:116-122.

22 Garty BZ, Levinson AI, Danon YL, Wilmott R, Douglas SD: Lymphocyte subpopulations in children with abnormal lymphatic circulation. J Allergy Clin Immunol 1989;84:515520.

23 Saeedian M, Randhawa I: Immunoglobulin replacement therapy: a twenty-year review and current update. Int Arch Allergy Immunol 2014;164:151-166.

24 Zaupper LB, Nielsen BW, Herlin T: Proteinlosing enteropathy after the total cavopulmonary connection: impact of intravenous immunoglobulin. Congenit Heart Dis 2011;6: 624-629. 